\title{
Sulfate source apportionment in the Ny-Ålesund (Svalbard Islands) Arctic aerosol
}

\author{
Roberto Udisti $^{1} \cdot$ Andrea Bazzano $^{2} \cdot$ Silvia Becagli $^{1} \cdot$ Ezio Bolzacchini $^{3} \cdot$ Laura Caiazzo $^{1} \cdot$ \\ David Cappelletti ${ }^{4} \cdot$ Luca Ferrero $^{3} \cdot$ Daniele Frosini $^{1} \cdot$ Fabio Giardi $^{1} \cdot$ Marco Grotti $^{2}$

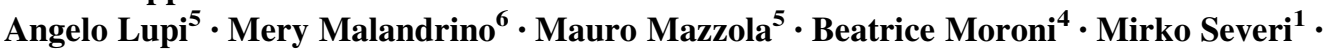 \\ Rita Traversi ${ }^{1} \cdot$ Angelo Viola $^{7} \cdot$ Vito Vitale $^{5}$
}

Received: 25 November 2015 / Accepted: 26 February 2016/Published online: 28 March 2016

(C) Accademia Nazionale dei Lincei 2016

\begin{abstract}
Daily PM10 aerosol samples were collected at the Gruvebadet observatory, Ny-Ålesund (Svalbard Islands), during the spring-summer 2014 Italian Arctic Campaign. A total of 136 samples were analysed for ion (inorganic anions and cations, selected organic anions) composition aiming to evaluate the seasonal pattern of sulfate, as a key component of the Arctic haze. Ionic balances indicated a strong sulfate seasonality with mean spring concentration about 1.5 times higher than that
\end{abstract}

This peer-reviewed article is a result of the multi and interdisciplinary research activities based at the Arctic Station "Dirigibile Italia", coordinated by the "Dipartimento Scienze del Sistema Terra e Tecnologie per l'Ambiente" of the National Research Council of Italy.

Roberto Udisti

udisti@unifi.it

Andrea Bazzano

andrea.bazzano@edu.unige.it

Silvia Becagli

silvia.becagli@unifi.it

Ezio Bolzacchini

ezio.bolzacchini@unimib.it

Laura Caiazzo

laura.caiazzo@unifi.it

David Cappelletti

david.cappelletti@unipg.it

Luca Ferrero

luca.ferrero@unimib.it

Daniele Frosini

daniele.frosini@unifi.it

Fabio Giardi

fabio.giardi@unifi.it measured in summer. The spring and summer aerosol was almost neutral, indicating that ammonia was the major neutralizing agent for atmospheric acidic species. The linear regression between sulfate from potential acidic sources (non-sea salt sulfate and non-crustal sulfate) and ammonium indicated that the mean sulfate/ammonium ratio was intermediate between semi- $\left(\mathrm{NH}_{4} \mathrm{HSO}_{4}\right)$ and complete $\left(\left(\mathrm{NH}_{4}\right)_{2} \mathrm{SO}_{4}\right)$ neutralization. Using sea-salt sodium as sea-spray marker, non-sea-salt calcium as crustal marker and methanesulfonic acid as biogenic marker, a detailed source apportionment for sulfate was carried out. The anthropogenic input (calculated as the differences between total sulfate and the sum of sea-salt, crustal and biogenic contributes) was found to be the most relevant

\author{
Marco Grotti \\ grotti@unige.it \\ Angelo Lupi \\ a.lupi@isac.cnr.it \\ Mery Malandrino \\ mery.malandrino@unito.it \\ Mauro Mazzola \\ m.mazzola@isac.cnr.it \\ Beatrice Moroni \\ b.moroni@tiscali.it \\ Mirko Severi \\ mirko.severi@unifi.it \\ Rita Traversi \\ rita.traversi@unifi.it \\ Angelo Viola \\ a.viola@isac.cnr.it \\ Vito Vitale \\ v.vitale@isac.cnr.it
}


contribution to the sulfate budget in the Ny-Ålesund aerosol in summer and, especially, in spring. In this last season, crustal, sea-salt, biogenic and anthropogenic sources accounted for 3.3, 12.0, 11.5 and $74.8 \%$, respectively.

Keywords Arctic aerosol - Sulfate sources ·

Anthropogenic input · Biogenic emissions · Spring-summer pattern

\section{Introduction}

Atmospheric aerosol plays a key role in the complex feedback processes between climate forcings and environmental responses, through the interaction with the solar irradiance. Such interaction involves direct effects, by scattering and absorption processes (RFari-radiation forcing by aerosol-radiation interaction) and indirect effects on Earth albedo (RFaci-radiation forcing by aerosol-cloud interaction), because atmospheric particles act as cloud condensation nuclei (IPCC 2013). By considering scattering and absorption processes of several aerosol components, the IPCC (2013) Report estimates that the RFari effect accounts for an overall cooling forcing of about $-0.35 \mathrm{~W} / \mathrm{m}^{2}$, with a large uncertainty $\left( \pm 0.5 \mathrm{~W} / \mathrm{m}^{2}\right)$. A similar cooling forcing $\left(-0.4 \mathrm{~W} / \mathrm{m}^{2}\right)$ is also exerted by the RFaci effect, with an even higher uncertainty (IPCC 2013). Such uncertainties are so large, with respect to the averaged RFari and RFaci values, to make uncertain also the sign of the forcing. This is particularly true for polar aerosol because, in the Polar Regions, the negative forcing by the surface albedo (snow cover and sea ice) is higher than that produced by cloud coverage and scattering processes, so leading to a positive aerosol forcing. Besides, size distribution and chemical composition data on polar aerosol have scarce spatial and temporal coverage, due to the little number of monitoring sites and logistic difficulties. Indeed, just few stations are carrying out continuous measurements on Arctic aerosol. These sites include: Alert

1 Department of Chemistry, University of Florence, 50019 Sesto Fiorentino, FI, Italy

2 Department of Chemistry and Industrial Chemistry, University of Genoa, 16146 Genoa, Italy

3 Department of Environmental Sciences, University of Milano-Bicocca, 20126 Milan, Italy

4 Dipartimento di Chimica, Biologia e Biotecnologie, Università Degli Studi di Perugia, 06123 Perugia, Italy

5 CNR-ISAC, 40129 Bologna, Italy

6 Department of Chemistry, University of Turin, 10125 Turin, Italy

7 CNR-ISAC, 00133 Rome, Italy
(Canadian Arctic), Station Nord (Northern Greenland), Zeppelin (Svalbard Islands), Barrow (Alaska), Karasjok and Svanvic (Northern Norway), Oulanka (Northern Finland) and Janiskoski (Northern Russia) (Quinn et al. 2007). The chemical characterization of aerosol collected in these stations revealed that the Arctic atmosphere is characterized by the so-called "Arctic haze", mainly occurring in spring. This phenomenon was at the beginning attributed to natural processes affecting the atmosphere transparency but, since late 1970s, the anthropogenic origin of the Arctic haze (via atmospheric transport of contaminants from polluted continental areas) was established by the chemical composition of the atmospheric particulate (see Quinn et al. 2007, for references). The Arctic haze is mainly composed by a mixture of sulfate, organic particulate matter, ammonium, nitrate, dust, black carbon and heavy metals ( $\mathrm{Li}$ and Barrie 1993; Quinn et al. 2002, 2007), in particles especially distributed in the accumulation mode (Tunved et al. 2013).

As sulfate is the dominant component in the Arctic haze, several studies were carried out to understand the inter- and intra-annual trends of sulfur-cycle compounds in the Arctic aerosol (e.g., Hara et al. 2003; Scheuer et al. 2003; Quinn et al. 2007; VanCuren et al. 2012; Nguyen et al. 2013) and in ice cores drilled in northern hemisphere (e.g., Isaksson et al. 2005; Goto-Azuma and Koerner 2001). In particular, extensive data set of aerosol chemical composition are available for the Zeppelin Station (Ny-Ålesund, 78 $54^{\prime} 29^{\prime \prime}$ $\mathrm{N}, 11^{\circ} 52^{\prime} 53^{\prime \prime} \mathrm{E}, 474.0 \mathrm{~m}$ a.s.l.) at the WEB site ebas.nilu.no (e.g., Aas et al. 2015).

Since 2010, an Italian infrastructure (Gruvebadet observatory) was installed in Ny-Ålesund (Svalbard Islands), aiming to study the physical and chemical properties of the Arctic aerosol (Viola et al. 2013; Udisti et al. 2013; Calzolai et al. 2014; Moroni et al. 2015; Bazzano et al. 2015). At the Gruvebadet observatory, aerosol samples were collected in the spring-summer period at different resolution by several sampling devices, including $\mathrm{PM}_{10}$ samplers and multi-stage impactors.

Here, we report the record of spring-summer sulfate concentrations measured at daily resolution during the 2014 Italian Arctic Campaign. Particular effort was made to identify and quantify the natural and anthropogenic sources of sulfate particulate reaching Ny-Ålesund, by using specific markers for sea spray, crustal and biogenic sources (anthropogenic contribution was evaluated by difference with respect to the total sulfate content).

To our knowledge, this is the first complete source apportionment of sulfate in the Arctic aerosol.

Results here reported can be useful in evaluating the relevance of the impact of anthropogenic aerosol on the critical Arctic ecosystem and in improving climate models based on aerosol-solar irradiation feedback processes. 


\section{Methodology}

\subsection{Sampling area}

The spring-summer 2014 campaign was carried out at the Gruvebadet Observatory (GVB), located at about $50 \mathrm{~m}$ a.s.1., $800 \mathrm{~m}$ south-west from the Ny-Ålesund village $\left(78^{\circ} 55^{\prime} \mathrm{N}, 11^{\circ} 56^{\prime} \mathrm{E}\right)$, Svalbard Islands. Ny-Ålesund is located in the Kongsfjorden fiord that develops in the north-west south-east direction, so that dominant winds are channelled in the same direction. In this way, the geographical position of the GVB observatory guarantees for the lowest impact form local emissions. Besides, around GVB, especially in the north-east side overlooking the NyÅlesund village, a clean area was established and snow mobile traffic and other potentially contaminant activities were forbidden.

Figure 1 shows the Ny-Ålesund area satellite view, where the Zeppelin Station and Gruvebadet Observatory are marked. In the same figure, the wind direction and speed mean values are reported for the period AprilSeptember 2014. The wind rose was obtained from Amundsen-Nobile Climate Change Tower measurements (CCT, Mazzola et al. 2016). The CCT is located about
$1 \mathrm{~km}$ away from Gruvebadet, in the West direction. The two most frequent flows are those from the Kongsvegen glacier (direction E-SE) and from the Brøggerbreen glaciers (direction S-SW). The third notable flow is again along the fiord, but coming from the open sea (direction W-NW), and it is mostly present during summer. These results are consistent with those from Maturilli et al. (2013), obtained from another nearby meteorological station. It is important to note that the contribution of wind coming from the Ny-Ålesund village is practically absent, therefore excluding a significant local anthropogenic contamination of the aerosol samples.

\subsection{Aerosol sampling}

Aerosol samples were continuously collected on daily basis (00:01-23:59, Universal Time Coordinated-UTC) from 31 March to 09 September 2014, by a Tecora SkyPost lowvolume sampler, equipped with a $\mathrm{PM}_{10}$ (particulate matter smaller than $10 \mu \mathrm{m}$ aerodynamic equivalent diametera.e.d.) head. Samplings were carried out in actual conditions: pressure and temperature were continuously monitored to maintain a constant flow rate of $38.3 \mathrm{~L} / \mathrm{min}$ (EN 12341 European rules), corresponding to a $24 \mathrm{~h}$ air volume

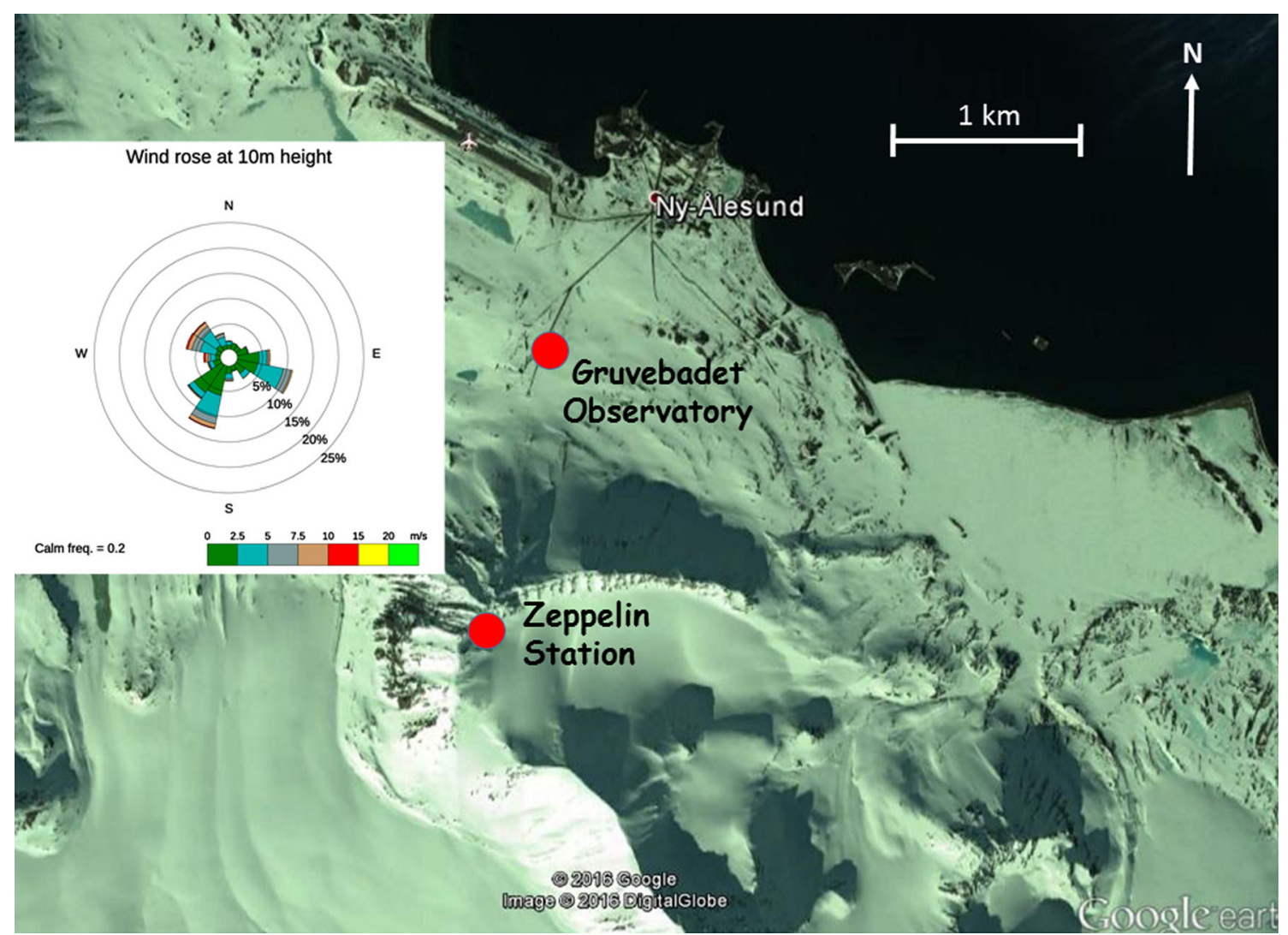

Fig. 1 Satellite view of the Ny-Ålesund area with wind rose for the period April-September 2014. The sites of Gruvebadet and Zeppelin are also marked 
of about $55 \mathrm{~m}^{3}$. Particulate matter was collected on Teflon filters (Pall R2PJ047, $47 \mathrm{~mm}$ diameter, $2 \mu \mathrm{m}$ nominal porosity). After sampling, filters were individually sealed in pre-washed (Milli-Q water, 18.3 M $\Omega$ ) polystyrene filter containers and stored at $-20{ }^{\circ} \mathrm{C}$ until analysis. $\mathrm{PM}_{10}$ mass was measured by weighing the filters with a microbalance (0.01 mg sensitivity) before and after exposure. The filters were conditioned at low humidity (silica gel) and controlled temperature $\left(25 \pm 1{ }^{\circ} \mathrm{C}\right)$ for at least $24 \mathrm{~h}$ before the weighing. A sample loss occurred in the periods 19th Apr7th May and 07th-12th August due to system failures. During the 2014 campaign, a total of 136 samples were collected.

At the analysis time, one half of each $\mathrm{PM}_{10}$ Teflon filter was extracted in about $10 \mathrm{ml}$ Milli-Q water (accurately evaluated by weighing) by ultrasonic bath for $20 \mathrm{~min}$, for ionic content determination. Every filter manipulation was carried out under a class-100 laminar-flow hood, to minimize contamination risks. Inorganic anions and cations, as well as selected organic anions, were simultaneously measured by using a three Dionex ion-chromatography system, equipped with electrochemical-suppressed conductivity detectors. The sample handling during the IC injection was minimized by using a specifically-designed Flow-Injection Analysis (IC-FIA) device (Morganti et al. 2007). Cations $\left(\mathrm{Na}^{+}, \mathrm{NH}_{4}{ }^{+}, \mathrm{K}^{+}, \mathrm{Mg}^{2+}\right.$ and $\mathrm{Ca}^{2+}$ ) were determined by using a Dionex CS12A-4 mm analytical column with $20 \mathrm{mM} \mathrm{H}_{2} \mathrm{SO}_{4}$ eluent. Inorganic anions $\left(\mathrm{Cl}^{-}\right.$, $\mathrm{NO}_{3}{ }^{-}, \mathrm{SO}_{4}{ }^{2-}$ and $\mathrm{C}_{2} \mathrm{O}_{4}{ }^{2-}$ ) were measured by a Dionex AS4A-4 mm analytical column with a $1.8 \mathrm{mM} \mathrm{Na}_{2} \mathrm{CO}_{3} /$ $1.7 \mathrm{mM} \mathrm{NaHCO} 3$ eluent. $\mathrm{F}^{-}$and some organic anions (acetate, glycolate, formate and methanesulfonate) were determined by a Dionex AS11 separation column by a gradient elution (0.075-2.5 mM Na${ }_{2} \mathrm{~B}_{4} \mathrm{O}_{7}$ eluent). A sixstandard calibration curve was daily used for quantification. Further details are reported in Udisti et al. (2004) and Becagli et al. (2011).

Here, only sulfate data are in depth discussed, referring to sodium, calcium, ammonium and methanesulfonic acid just as ancillary measurements. PM10 atmospheric load (by filter weighing) and ions concentrations will be discussed in a further paper.

\subsection{Calculation of the ion fractions}

Ny-Ålesund aerosol contains not-negligible contributions of sea salt and crustal components, so that $\mathrm{Na}^{+}$and $\mathrm{Ca}^{2+}$, which originate from both these sources, cannot be used as univocal sea spray and crustal markers, respectively. To quantify the sea-salt (ss-) and non-sea-salt (nss-) contributions of these elements in every sample, we used a simple equation system (Becagli et al. 2012; Udisti et al. 2012):

$$
\begin{aligned}
& \text { tot- } \mathrm{Na}^{+}=\mathrm{ss}-\mathrm{Na}^{+}+\mathrm{nss}-\mathrm{Na}^{+} \\
& \text {tot }-\mathrm{Ca}^{2+}=\mathrm{ss}-\mathrm{Ca}^{2+}+\mathrm{nss}-\mathrm{Ca}^{2+} \\
& \text { ss- } \mathrm{Na}^{+}=\text {tot }-\mathrm{Na}^{+}-0.562 \mathrm{nss}-\mathrm{Ca}^{2+} \\
& \mathrm{nss}^{2+} \mathrm{Ca}^{2+}=\text { tot }-\mathrm{Ca}^{2+}-0.038 \mathrm{ss}-\mathrm{Na}^{+}
\end{aligned}
$$

where 0.562 represents the $\mathrm{Na}^{+} / \mathrm{Ca}^{2+}$ weight-to-weight (w/w) ratio in the crust (Bowen 1979), and 0.038 is the $\mathrm{Ca}^{2+} / \mathrm{Na}^{+}$w/w ratio in seawater (Nozaki 1997).

The sea-salt fraction of sulfate ( $\mathrm{ss}-\mathrm{SO}_{4}{ }^{2-}$ ) was calcu-

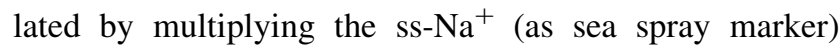
concentration by 0.253 (indicating the $\mathrm{SO}_{4}{ }^{2-} / \mathrm{Na}^{+} \mathrm{w} / \mathrm{w}$ ratio in seawater-Bowen 1979).

The non-sea-salt fraction of sulfate (nss- $\mathrm{SO}_{4}{ }^{2-}$ ) was calculated by subtracting the $\mathrm{ss}-\mathrm{SO}_{4}{ }^{2-}$ contribution from the tot- $\mathrm{SO}_{4}{ }^{2-}$ concentrations.

The crustal fraction of sulfate $\left(\mathrm{cr}^{-} \mathrm{SO}_{4}{ }^{2-}\right)$ was estimated by multiplying the nss- $\mathrm{Ca}^{2+}$ (as crustal marker) content by $0.59\left(\mathrm{SO}_{4}{ }^{2-} / \mathrm{Ca}^{2+} \mathrm{w} / \mathrm{w}\right.$ ratio in the uppermost Earth crustWagenbach et al. 1996).

The sulfate contribution from marine phytoplanktonic activity (via atmospheric oxidation of dimethylsulfideDMS-emitted from micro-algal population) was estimated by multiplying the methanesulfonate (MSA — as specific marker of marine biogenic emissions) concentration by 3.0 (see, Sect. 3.3).

\section{Result and discussion}

\subsection{Ionic balances}

Figure 2 shows the ionic balances (expressed as $\mathrm{nEq} / \mathrm{m}^{3}$ ) of the $\mathrm{PM}_{10}$ aerosol samples collected in $\mathrm{Ny}$-Ålesund during the spring-summer 2014 campaign (136 samples).

The ionic composition is dominated by two main components: sea spray (marked by $\mathrm{Na}^{+}, \mathrm{Cl}^{-}, \mathrm{Mg}^{2+}$ and, partially, $\mathrm{SO}_{4}{ }^{2-}$ ) and secondary aerosol (marked by sulfate, ammonium, nitrate and nitrite). The all-period (total) plot shows that $\mathrm{Na}^{+}$and $\mathrm{NH}_{4}^{+}$were the major cations, accounting for 51 and $25 \%$ of the cation content,

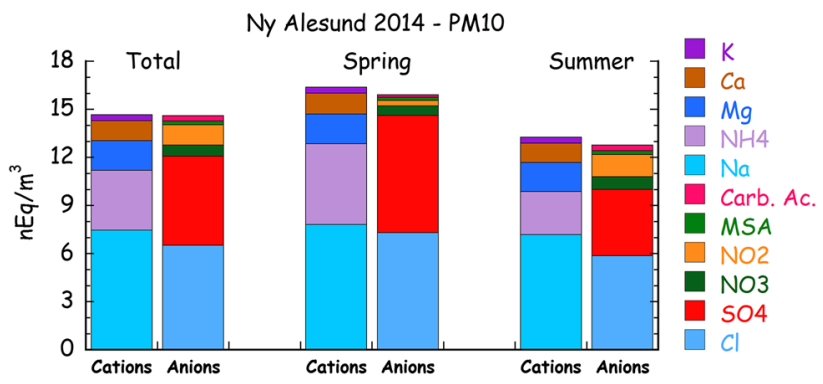

Fig. 2 Ionic balances (in $\mathrm{nEq} / \mathrm{m}^{3}$ ) for all-period (total) and seasonal aerosol samples collected at Ny-Ålesund during the 2014 campaign 


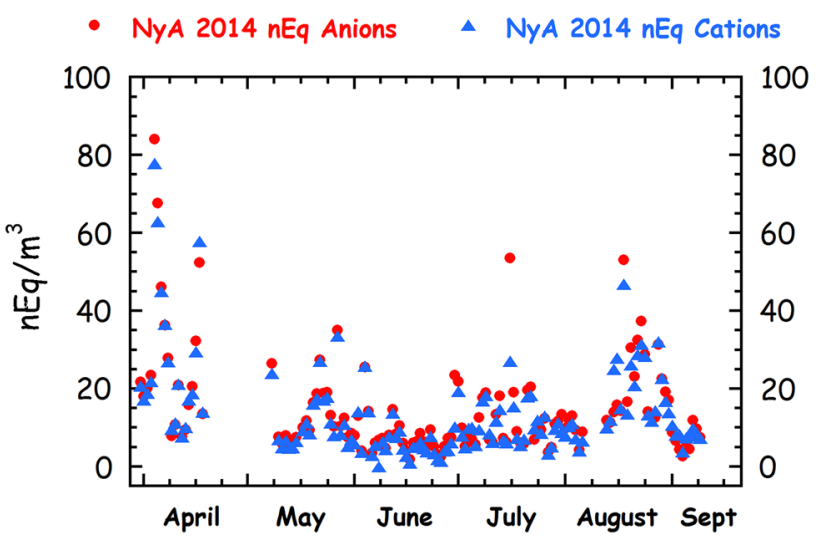

Fig. $3 \mathrm{Ny}$-Ålesund $\mathrm{PM}_{10}$ anions (red dot) and cations (blue triangle) budget $\left(\mathrm{nEq} / \mathrm{m}^{3}\right)$ along the sampling period

respectively. In the same way, chloride and sulfate dominate the anion budget (45 and $38 \%$, respectively). Such components, however, are not equally distributed in the spring and summer samples, showing a sharp seasonal pattern. Indeed, sulfate and ammonium show the highest contribution (both in absolute quantity and in ion percentage) in spring. In this season, $\mathrm{NH}_{4}{ }^{+}$accounts for $30 \%$ of the cation budget, while $\mathrm{SO}_{4}{ }^{2-}$ reaches a contribution as high as $46 \%$ of the anion content. In particular, sulfate accounts for $19 \%\left(5.6 \mathrm{nEq} / \mathrm{m}^{3}\right), 23 \%\left(7.3 \mathrm{nEq} / \mathrm{m}^{3}\right)$ and $16 \%\left(4.1 \mathrm{nEq} / \mathrm{m}^{3}\right)$ of the total ion content (anions plus cations) in all-period, spring and summer samples, respectively. All-period and seasonal ionic balances show that anions and cations are almost balanced, indicating a quite completely neutralized aerosol. Figure 3 shows the anions and cations sums $\left(\right.$ as $\mathrm{nEq} / \mathrm{m}^{3}$ ) for all the collected samples. Besides experimental errors (cumulative uncertainties evaluated around $10 \%$ ), anions and cations are also balanced day by day, with very few exceptions (4-5 April, 15 July, 18 August), when a significant free acidity is evident (especially on 15 July). This evidence means that acidic species, such as $\mathrm{H}_{2} \mathrm{SO}_{4}$ and $\mathrm{HNO}_{3}$, were almost neutralized by ammonia, to give ammonium salts, in the atmosphere during the transport from the source areas to the deposition site.

\subsection{Total sulfate profile}

Figure 4 shows the temporal profile of total sulfate measured at the GVB (this paper) and Zeppelin (Aas et al. 2015) sites in the period 31 March-09 September 2014. Unfortunately, continuous daily Zeppelin data are available just up to 10 July, so that the comparison can be carried out only for the late spring to early summer period. Besides, we have to note that Zeppelin data are more representative of free tropospheric circulation (474 $\mathrm{m}$ a.s.l.), while the measurements at GVB (50 m a.s.1.) are strongly related to

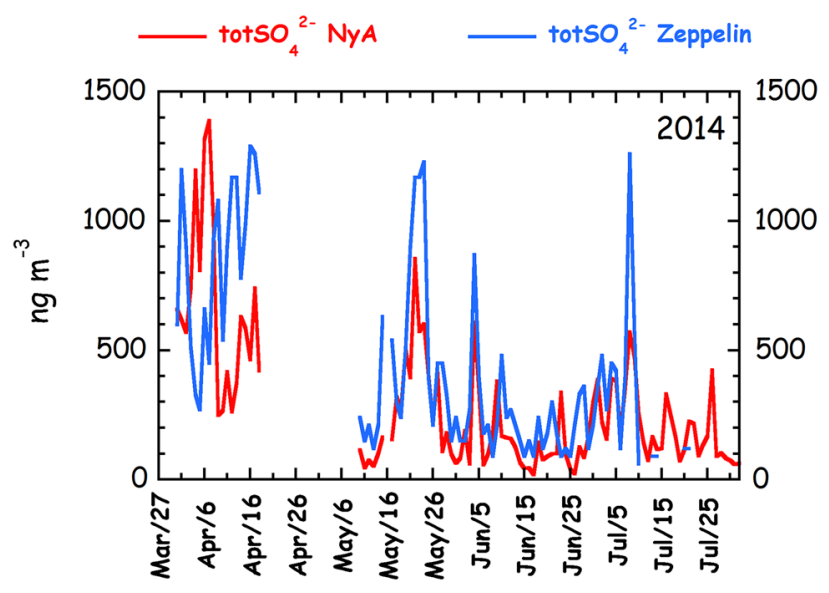

Fig. 4 Comparison between the total sulfate atmospheric concentrations at Ny-Ålesund (red line) and Zeppelin (blue line) in the spring-mid summer 2014

the Planetary Boundary Layer (PBL) dynamics, so that the aerosol concentrations are affected by the height of the mixing layer. In spite of the different sampling cut-off (PM10 for NyA and Total Suspended Particulate-TSPfor Zeppelin), the sulfate profiles match quite well in the summer (May-early July), even if the sulfate spikes around 21 May, 04 June and 08 July show significantly higher concentrations at the Zeppelin site. On the contrary, spring profiles are quite different, possibly due to the different aerosol atmospheric load below and above the PBL in such period, when the vertical atmospheric structure is well layered.

\subsection{Sulfate/ammonium relationship}

To evaluate the neutralizing effect of ammonia on $\mathrm{H}_{2} \mathrm{SO}_{4}$, we studied the relationship between the concentrations of $\mathrm{NH}_{4}{ }^{+}$and of the sulfate species mainly originated in acidic form. Sea-salt sulfate originates mainly as $\mathrm{Na}_{2} \mathrm{SO}_{4}$, and crustal sulfate as $\mathrm{CaSO}_{4}$. Therefore, their contribution has to be subtracted from the total sulfate content. By using ss$\mathrm{Na}^{+}$as sea spray marker and nss-Ca ${ }^{2+}$ as crustal indicator, the $\mathrm{ss}^{-\mathrm{SO}_{4}}{ }^{2-}$ and $\mathrm{cr}-\mathrm{SO}_{4}{ }^{2-}$ fractions were calculated, following the equations shown in Sect. 2.3, and their values were removed from the tot- $\mathrm{SO}_{4}{ }^{2-}$ concentration, then obtaining the nss-nc- $\mathrm{SO}_{4}{ }^{2-}$ fraction. By plotting nss-nc$\mathrm{SO}_{4}{ }^{2-}$ vs. $\mathrm{NH}_{4}{ }^{+}$concentrations, it was possible to evaluate if $\mathrm{NH}_{3}$ is a relevant neutralizing agent for $\mathrm{H}_{2} \mathrm{SO}_{4}$ and to estimate the neutralization level.

Figure 5 shows that nss-nc- $\mathrm{SO}_{4}{ }^{2-}$ and $\mathrm{NH}_{4}{ }^{+}$concentrations are significantly correlated (linear regression; $R=0.94, n=136$ ), so demonstrating that sulfate is present in the Ny-Ålesund aerosol as ammonium salt. The slope of the linear regression (3.59) represents an intermediate value between the $\mathrm{SO}_{4}{ }^{2-} / \mathrm{NH}_{4}{ }^{+}$ratios of 2.66 


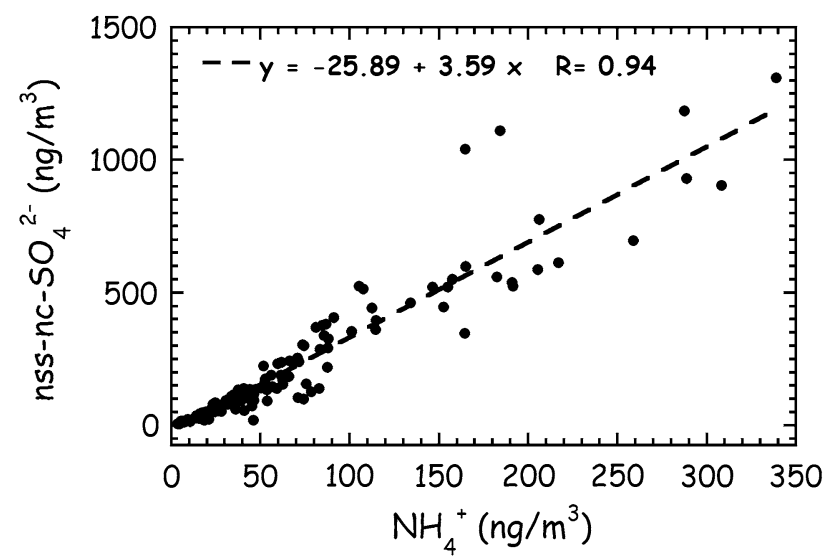

Fig. 5 Linear relationship between nss-nc- $\mathrm{SO}_{4}{ }^{2-}$ and $\mathrm{NH}_{4}{ }^{+}$concentrations in $2014 \mathrm{Ny}$-Ålesund aerosol samples

(corresponding to the w/w ratio in $\left(\mathrm{NH}_{4}\right)_{2} \mathrm{SO}_{4}$ salt) and $5.33\left(\mathrm{SO}_{4}{ }^{2-} / \mathrm{NH}_{4}{ }^{+}\right.$w/w ratio in $\left.\mathrm{NH}_{4} \mathrm{HSO}_{4}\right)$. Therefore, the sulfate is present in both these species in spring-summer 2014 Ny-Ålesund aerosol.

Figure 6 shows the temporal trend of the nss-nc- $\mathrm{SO}_{4}{ }^{2-}$ / $\mathrm{NH}_{4}^{+}$w/w ratio along all the sampling period. It is evident that nss-nc- $\mathrm{SO}_{4}{ }^{2-}$ is contemporaneously present both as completely $\left(\left(\mathrm{NH}_{4}\right)_{2} \mathrm{SO}_{4}\right)$ or partially $\left(\mathrm{NH}_{4} \mathrm{HSO}_{4}\right)$ neutralized form in the majority of samples, with a significant exception for a short transport event occurred on 15-16 August 2014. In these days, the nss-nc- $\mathrm{SO}_{4}{ }^{2-} / \mathrm{NH}_{4}{ }^{+} \mathrm{w} / \mathrm{w}$ ratio reaches values as high as 6.31 , indicating the presence of sulfate in acidic form $\left(\mathrm{H}_{2} \mathrm{SO}_{4}\right)$.

\subsection{Sulfate biogenic contribution}

As above discussed, the nss-nc- $\mathrm{SO}_{4}{ }^{2-}$ fraction can be attributed to the sum of the species originated in acidic form. The main sources of $\mathrm{H}_{2} \mathrm{SO}_{4}$ are the anthropogenic emissions and the marine biogenic activity. While source markers of anthropogenic emissions are difficult to interpret, the contribution of the phytoplanktonic metabolic processes can be evaluated by using MSA as their univocal marker. Therefore, the anthropogenic impact on the sulfate budget was evaluated by subtracting the biogenic sulfate (bio- $\mathrm{SO}_{4}{ }^{2-}$ ) fraction from the nss-nc-SO ${ }_{4}{ }^{2-}$ concentrations.

Phytoplanktonic metabolic processes produce dimethylsulfoniopropionate (DMSP) as an osmolyte. DMSP is broken down by marine microbial species to form two major volatile sulfur compounds: methanethiol $\left(\mathrm{CH}_{3} \mathrm{SH}\right)$ and dimethylsulfide (DMS- $\left.-\mathrm{CH}_{3}-\mathrm{S}-\mathrm{CH}_{3}\right)$. While methanethiol is rapidly assimilated by bacteria into sulfurproteins, DMS bacteria uptake is slower and this compound, scarcely soluble in seawater, is emitted into the atmosphere, where it is oxidized to methanesulfonic acid (MSA) and $\mathrm{H}_{2} \mathrm{SO}_{4}$ (Bates et al. 1992; Saltzman 1995; Kettle and Andreae 2000). On global scale, the MSA and $\mathrm{H}_{2} \mathrm{SO}_{4}$ aerosol originated from marine biogenic emissions affects the Earth's radiative budget by direct (solar irradiation scattering) and indirect (they act as cloud condensation nuclei and affect surface albedo) way (e.g., Kaufman et al. 2002; Gondwe et al. 2003). For these effects, the marine biogenic emissions are believed to play a relevant negative feedback on climate change (CLAW hypothesis, Charlson et al. 1987). A strong relationship between aerosol MSA and marine primary productivity was found by Becagli et al. (2013), in the Southern Mediterranean Sea. Besides, nss- $\mathrm{SO}_{4}{ }^{2-}$ from marine biogenic emissions was used by Wolff et al. (2006), as a specific marker to reconstruct marine biogenic activity for the last $800 \mathrm{kyr}$ by ice core analysis.

While $\mathrm{H}_{2} \mathrm{SO}_{4}$ at present in the Arctic is originated mainly from anthropogenic emission, MSA is a univocal marker of the biogenic emissions. Therefore, the bio- $\mathrm{SO}_{4}{ }^{2-}$ fraction can by evaluated if the $\mathrm{SO}_{4}{ }^{2-}$ /MSA ratio from DMS oxidation is known. Unfortunately, this ratio is highly variable and it depends from latitude, air temperature and photochemistry efficiency (e.g., Bates et al. 1992; Barone et al. 1995; Hynes et al. 1986; Leck et al. 2002; Turnipseed et al. 1996).

To understand the relationship between $\mathrm{MSA}$ and $\mathrm{SO}_{4}{ }^{2-}$ from biogenic emission, we plotted the nss-nc- $\mathrm{SO}_{4}{ }^{2-} / \mathrm{MSA}$
Fig. 6 Temporal trend of the nss-nc- $\mathrm{SO}_{4}{ }^{2-} / \mathrm{NH}_{4}{ }^{+}$w/w ratio along the $2014 \mathrm{Ny}-\AA$ Alesund campaign (see text for values interpretation)

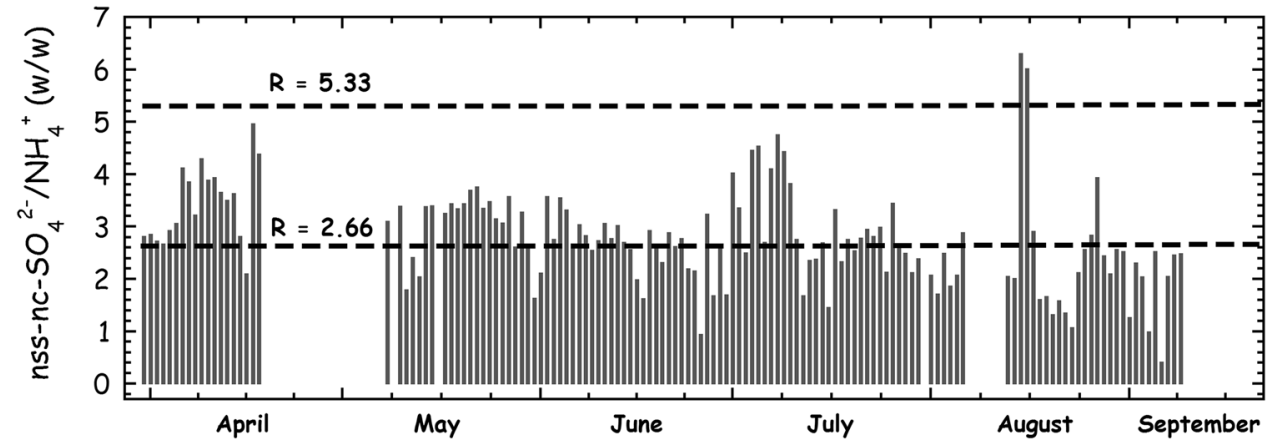




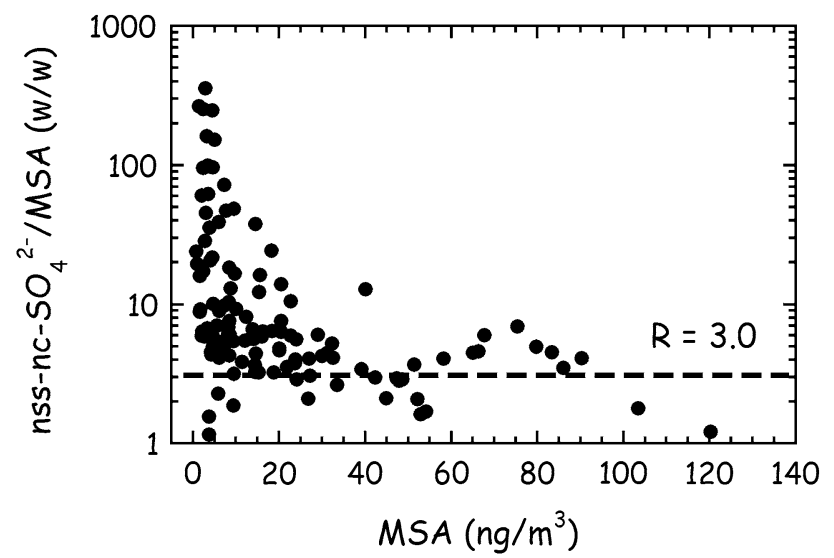

Fig. 7 Relationship between the nss-nc-SO ${ }_{4}{ }^{2-} / \mathrm{MSA} w / \mathrm{w}$ ratio and MSA concentration in all-period $2014 \mathrm{Ny}$-Ålesund aerosol samples

w/w ratio vs. MSA concentration measured in the $\mathrm{PM}_{10}$ samples, aiming to find a limit ratio when MSA (i.e. biogenic contribution) is high. Figure 7 shows that the nss-nc$\mathrm{SO}_{4}{ }^{2-} / \mathrm{MSA}$ ratio tends to be 3.0. This value is similar to other values measured in Polar Regions during summer campaigns. Teinilä et al. (2003) found nss-SO ${ }_{4}{ }^{2-} / \mathrm{MSA}$ ratios ranging from 77 to 3.8 at ground level in Ny-Ålesund. In the same site, by using multistage impactor data, Teinilä et al. (2004) calculated a value around 5 in the sub micrometric fraction. In central Arctic Ocean, Chang et al. (2011) found a value of 4, while Leck and Persson (1996) calculated a ratio $=4.5$ in the sub micrometric aerosol fraction. Values closer to that we have observed as biogenic limiting value were reported at Alert (Canada) by Norman et al. (1999) $\left(\mathrm{nss}-\mathrm{SO}_{4}{ }^{2-} / \mathrm{MSA}=2.6\right)$ and by $\mathrm{Li}$ and Barrie $(1993) \quad\left(\right.$ nss-SO $\left.{ }_{4}{ }^{2-} / \mathrm{MSA}=1.7\right)$. In East Antarctic Plateau (Concordia Station), by using the same approach, Udisti et al. (2012) found the value of 2.6 for a multi-year aerosol database. The ratio $=3.0$ evaluated in the 2014 GVB data set is very close to that obtained by the AOE-96 box-model (mean nss-SO ${ }_{4}{ }^{2-} / \mathrm{MSA}=3.1$, Karl et al. 2007), and slightly higher than those calculated by a chemical transport model (1.5-2.6; Gondwe et al. 2006).

By using the $\mathrm{SO}_{4}{ }^{2-} / \mathrm{MSA}$ ratio $=3$ in biogenic aerosol originated in the Arctic sea areas, the bio- $\mathrm{SO}_{4}{ }^{2-}$ fraction can be evaluated by multiplying the MSA concentrations, measured in the Ny-Ålesund aerosol samples, by this value.

\subsection{Sulfate anthropogenic fraction}

Following the above discussion, the anthropogenic contribution to the sulfate budged (anthr- $\mathrm{SO}_{4}{ }^{2-}$ ) in every aerosol sample is evaluated by subtracting the sum of the $\mathrm{ss}^{-\mathrm{SO}_{4}}{ }^{2-}$, cr- $\mathrm{SO}_{4}{ }^{2-}$ and bio- $\mathrm{SO}_{4}{ }^{2-}$ fractions from the tot- $\mathrm{SO}_{4}{ }^{2-}$ concentration.

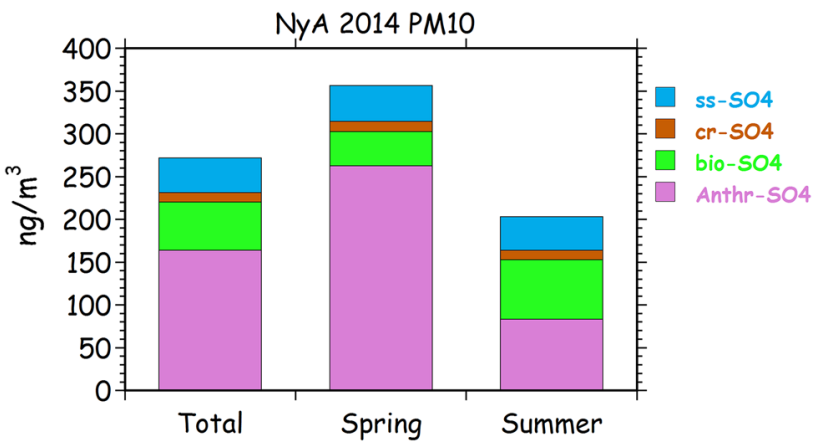

Fig. 8 All-period and seasonal contribution of sea salt, crustal, biogenic and anthropogenic fractions to the sulphate budget in 2014 Ny-Ålesund aerosol

Table 1 Sulfate source apportionment $\left(\mathrm{ng} / \mathrm{m}^{3}\right)$ for $\mathrm{Ny}$ - $\mathrm{Alesund}$ summer-spring $\mathrm{PM}_{10}$ samples

\begin{tabular}{lccc}
\hline & All period & Spring & Summer \\
\hline Anthrop. sulfate & 163.7 & 262.4 & 83.4 \\
Biogenic sulfate & 56.4 & 40.3 & 69.5 \\
Sea-salt sulfate & 40.6 & 42.2 & 39.3 \\
Crustal sulfate & 11.2 & 11.6 & 10.8 \\
\hline
\end{tabular}

Figure 8 and Table 1 shows the mean values of the contribution of the four sulfate fractions to the sulfate budget in all period and in spring and summer samples. In all-period samples, ss-, cr-, bio- and anthr-sulfate fractions account for 15.2, 4.2, 21.2 and $61.2 \%$ of the total sulfate budget, respectively. It is evident that the anthropogenic emissions play a dominant role in the sulfate atmospheric concentration at Ny-Ålesund, with a minor, but significant, contribution from sea spray and biogenic sources. On the contrary, the crustal contribution is quite low. More interesting information can be retrieved by the seasonal pattern. In the spring samples, the anthropogenic contribution is very high (covering the $74.8 \%$ of the sulfur budget), so demonstrating the effect of "Arctic haze" transport events, which are more probable and intense in this season (Quinn et al. 2007), due to the inefficient pollutants dispersal, slow removal rates and isentropic transport into the Arctic as low-pressure systems run-up against quasi-stationary Siberian high (Barrie 1986). In summer, the impact of the anthropogenic source is lower (42\%), with a contribution comparable to that coming from biogenic emissions (35\%), which reaches absolute and percentage values about two times higher than those measured in spring.

The ss-contribution is quite constant (as absolute concentration) in the two seasons, but the percentage contribution is significantly higher in summer $(19.8 \%)$ than in spring $(12.0 \%)$. 
Fig. 9 Temporal trend of the contribution of sea salt, crustal, biogenic and anthropogenic fractions to the sulphate budget in $2014 \mathrm{Ny}$-Ålesund aerosol

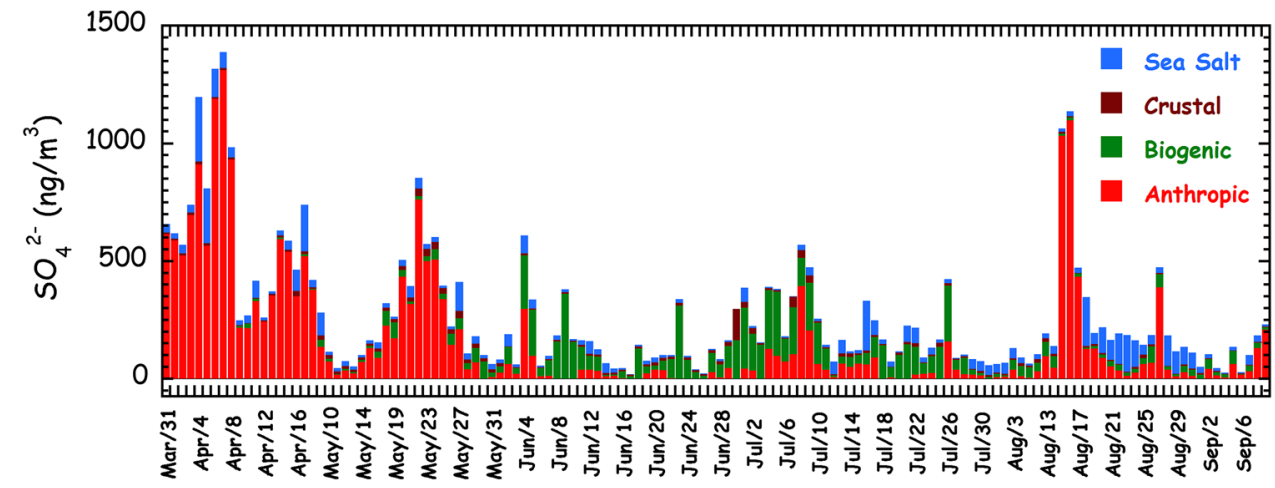

The crustal source plays a minority role. The all-period contribution is $4.2 \%$ of the sulfate budget. Likewise ss$\mathrm{SO}_{4}{ }^{2-}$, the absolute concentrations of $\mathrm{cr}-\mathrm{SO}_{4}{ }^{2-}$ are similar in spring and summer, but summer percentage is higher (5.5\%, with respect to $3.3 \%$ in spring), due to the larger sulfate atmospheric concentrations in spring, especially caused by anthropogenic Arctic haze transport.

Figure 9 shows the temporal distribution of the four sulfate fractions along all the sampling period. A dominant anthropogenic contribution is visible in the aerosol samples from 31 March to end of May, in the period 03-10 June and during a sharp event on 15-16 August. Scheuer et al. (2003) showed that, as the spring season progresses, surface haze diminishes and sulfate starts to decline. In summer, sulfate aerosol is efficiently removed from the atmosphere by low-level clouds and wet deposition processes (Scheuer et al. 2003). Sea spray sulfate is especially large in sporadic spring events and, consistently, in the period 17-31 August. The biogenic sources are relevant from early June to the end of July. The sulfate crustal fraction is visible (but scarcely relevant) in the period 19-25 May and in sporadic samples in late June-early July (especially in the 30 June sample). The higher summer values are possibly due to the contribution of local dust after the snow coverage melting.

In conclusion, the anthropogenic sources was found to be the major contribution to the sulfate budget in NyÅlesund aerosol, especially in spring, when the Arctic haze transport events are more frequent and intense.

\section{Conclusions}

A 4-term source apportionment of sulfate aerosol was accomplished on 136 PM10 filters collected on daily basis at Ny-Ålesund, Svalbard Islands, during the spring-summer 2014 campaign. The sea spray contribution was calculated from ss- $\mathrm{Na}^{+}$, used as sea spray marker; crustal fraction was evaluated by using nss-Ca ${ }^{2+}$ as crustal marker; the biogenic contribution was derived by MSA, as univocal phytoplanktonic emission indicator (via DMS atmospheric oxidation). Anthropogenic sulfate was obtained as a difference between the sum of the previously cited contributions and the total sulfate atmospheric concentration in every sample.

The sulfate probably emitted in acidic form (anthropogenic plus biogenic) was plotted as a function of ammonium, to evaluate the neutralization level from atmospheric ammonia. The linear regression was highly significant $(R=0.94 ; n=136)$ and indicated that the mean sulfate/ammonium ratio was intermediate between semi- $\left(\mathrm{NH}_{4} \mathrm{HSO}_{4}\right)$ and complete $\left(\left(\mathrm{NH}_{4}\right)_{2} \mathrm{SO}_{4}\right)$ neutralization. This is in agreement with the spring and summer ionic balances, where anion equivalent were completely counterbalanced by cations, avoiding the necessity to insert $\mathrm{H}^{+}$or $\mathrm{HCO}_{3}{ }^{-}$equivalents to compensate possible unbalances.

Sulfate source set showed a clear seasonal pattern. The anthropogenic fraction was dominant $(74.8 \%$ of the total sulfate budget) in spring (up to the end of May), probably due to Arctic haze transport events, and in two short transport events (early July and mid-August). Biogenic emissions were the main sulfate source from early June to early August, accounting for $35.0 \%$ in the summer samples. Sea salt aerosol contributed for about $20 \%$ in summer, while spring values were lower $(12.0 \%)$. The crustal fraction was always low, with a relatively higher contribution in summer $(5.5 \%)$.

To our knowledge, this is the first complete source apportionment of sulfate in the Arctic aerosol.

Results here reported can be useful in evaluating the relevance of the impact of anthropogenic aerosol on the critical Arctic ecosystem and in improving climate models based on aerosol-solar irradiation feedback processes.

Acknowledgments This study was partially funded by the Italian Ministry of University and Research (MIUR) within the framework of the PRIN-2009 project 20092C7KRC_002. The logistic assistance of the Polar Support Unit of the CNR Department of Earth and Environment (POLARNET) is gratefully acknowledged. This work was also partially supported by Italian MAE (Ministry of Foreign Affairs), within a bilateral cooperation program, in the framework of the ItalySouth Korea agreement 2013-2015. 


\section{References}

Aas W, Platt S, Solberg S, Yttri KE (2015) Monitoring of long-range transported air pollutants in Norway, annual report 2014. Kjeller, NILU (Miljødirektoratet rapport, M-367/2015) (NILU OR, 20/2015)

Barone SB, Turnipseed AA, Ravishankara AR (1995) Role of adducts in the atmospheric oxidation of dimethyl sulfide. Faraday Discuss 100:39-54

Barrie LA (1986) Arctic air pollution: an overview of current knowledge. Atmos Environ 20:643-663

Bates TS, Calhoun JA, Quinn PK (1992) Variations in the methanesulfonate to sulfate molar ratio in submicrometer marine aerosol particles over the south Pacific Ocean. J Geophys Res 97(D9):9859-9865

Bazzano A, Ardini F, Becagli S, Traversi R, Udisti R, Cappelletti D, Grotti M (2015) Source assessment of atmospheric lead measured at Ny-Ålesund, Svalbard. Atm Environ. 113:20-26

Becagli S, Ghedini C, Peeters S, Rottiers A, Traversi R, Udisti R, Chiari M, Jalba A, Despiau S, Dayan U, Temara A (2011) MBAS (Methylene Blue Active Substances) and LAS (Linear Alkylbenzene Sulphonates) in Mediterranean coastal aerosols: sources and transport processes. Atmos Environ 45:6788-6801. doi:10.1016/j.atmosenv.2011.04.041

Becagli S, Scarchilli C, Traversi R, Dayan U, Severi M, Frosini D, Vitale V, Mazzola M, Lupi A, Nava S, Udisti R (2012) Study of present-day sources and transport processes affecting oxidised sulphur compounds in atmospheric aerosols at Dome $\mathrm{C}$ (Antarctica) from year-round sampling campaigns. Atm Environ 52:98-108. doi:10.1016/j.atmosenv.2011.07.053

Becagli S, Lazzara L, Fani F, Marchese C, Traversi R, Severi M, di Sarra A, Sferlazzo D, Piacentino S, Bommarito C, Dayan U, Udisti R (2013) Relationship between methanesulfonate in atmospheric particulate and remotely sensed phytoplankton activity in oligo-mesotrophic central Mediterranean Sea. Atmos Environ 79:681-688. doi:10.1016/j.atmosenv.2013.07.032

Bowen HJM (1979) Environmental chemistry of the elements. Academic Press, London

Calzolai G, Chiari M, Lucarelli F, Nava S, Taccetti F, Becagli S, Frosini D, Traversi R, Udisti R (2014) PIXE-PIGE analysis of size-segregated aerosol samples from remote areas. Nucl Instr Methods Phys Resear B 318: 125-129

Chang RYW, Leck C, Graus M, Müller M, Paatero J, Burkhart JF, Stohl A, Orr LH, Hayden K, Li SM, Hansel A, Tjernström M, Leaitch WR, Abbatt JPD (2011) Aerosol composition and sources in the central Arctic Ocean during ASCOS. Atmos Chem Phys 11: 10619-10636. http://www.atmos-chem-phys.net/11/ 10619/2011/. doi:10.5194/acp-11-10619-2011

Charlson RJ, Lovelock JE, Andreae MO, Warren SG (1987) Oceanic phytoplankton, atmospheric sulphur, cloud albedo and climate. Nature 326(6114):655-661

Gondwe M, Krol M, Gieskes W, Klaassen W, de Baar H (2003) The contribution of ocean-leaving DMS to the global atmospheric burdens of DMS, MSA, $\mathrm{SO}_{2}$, and $\mathrm{nsSSO}_{4}{ }^{2-}$. Global Biogeochem Cycles 17(2):1056. doi:10.1029/2002GB001937

Gondwe M, Krol M, Klaassen W, Gieskes W, de Baar H (2006) Comparison of modeled versus measured MSA:nss SO4 ratios: A global analysis. Global Biogeochem Cy 18: GB2006. doi:10. 1029/2003GB002, 144

Goto-Azuma K, Koerner RM (2001) Ice core studies of anthropogenic sulfate and nitrate trends in the Arctic. J Geophys Res 106:4959-4969

Hara K, Yamagata S, Yamanouchi T, Sato K, Herber A, Iwasaka Y, Nagatani M, Nakata H (2003) J Geophys Res 108(D7):4209. doi:10.1029/2002JD002513
Hynes AJ, Wine PH, Semmes DH (1986) Kinetics and mechanism of hydroxyl reactions with organic sulfides. J Phys Chem 90:4148-4156

Isaksson E, Kekonen T, Moore J, Mulvaney R (2005) The methanesulfonic acid (MSA) record in a Svalbard ice core. Ann Glaciol 42:345-351

IPCC. Climate Change (2013) The physical sciences basis. IPCC Working Group I. Contribution to AR5

Karl M, Gross A, Leck C, Pirjola L (2007) Intercomparison of dimethylsulfide oxidation mechanisms for the marine boundary layer: gaseous and particulate sulfur constituents. J Geophys Res 112: D15304. doi:10.1029/2006JD007, 914

Kaufman YJ, Tanre D, Boucher O (2002) A satellite view of aerosols in the climate system. Nature 419(6903):215-223

Kettle AJ, Andreae MO (2000) Flux of dimethylsulfide from the oceans: a comparison of updated data sets and flux models. J Geophys Res 105(D22):26793-26808

Leck C, Persson C (1996) Seasonal and short-term variability in dimethyl sulfide, sulfur dioxide and biogenic sulfur and sea salt aerosol particles in the arctic marine boundary layer during summer and autumn. Tellus B 48:272-299

Leck C, Hetinzenberg J, Engard M (2002) A meridional profile of the chemical composition of submicrometer particles over the Atlantic Ocean: aerosol sources and hemispheric variabilities. Tellus B 54:377-384

Li SM, Barrie LA (1993) Biogenic sulfur aerosol in the Arctic troposphere: 1. contributions to total sulfate. J Geophys Res 98: $20613-20622$

Maturilli M, Herber A, König-Langlo G (2013) Climatology and time series of surface meteorology in Ny-Ålesund, Svalbard. Earth Syst Sci Data 5:155-163. doi:10.5194/essd-5-155-2013

Mazzola M, Viola AP, Lanconelli C, Vitale V (2016) Atmospheric observations at the Amundsen-Nobile Climate Change Tower in Ny-Ålesund, Svalbard. Rend Fis Acc Lincei (this issue)

Morganti A, Becagli S, Castellano E, Severi M, Traversi R, Udisti R (2007) An improved flow analysis-ion chromatography method for determination of cationic and anionic species at trace levels in Antarctic ice cores. Anal Chim Acta 603:190-198

Moroni B, Becagli S, Bolzacchini E, Busetto M, Cappelletti D, Crocchianti S, Ferrero L, Frosini D, Lanconelli C, Lupi A, Maturilli M, Mazzola M, Perrone MG, Sangiorgi G, Traversi R, Udisti R, Viola A, Vitale V (2015) Vertical profiles and chemical properties of aerosol particles upon Ny-Ålesund (Svalbard Island). Adv Meterol. Article ID 292081. doi:10.1155/2015/292081

Nguyen QT, Skov H, Sørensen LL, Jensen BJ, Grube AG, Massling A, Glasius M, Nøjgaard JK (2013) Source apportionment of particles at Station Nord, North East Greenland during 2008-2010 using COPREM and PMF analysis. Atmos Chem Phys 13:35-49

Norman AL, Barrie LA, Toom-Sauntry D, Sirois A, Krouse HR, Li SM, Sharma S (1999) Sources of aerosol sulphate at Alert: apportionment using stable isotopes. J Geophys Res 104(D9): 11619-11631

Nozaki Y (1997) A fresh look at element distribution in the North Pacific. http://www.agu.org/eos_elec/97025e.html

Quinn PK, Miller TL, Bates TS, Ogren JA, Andrews E et al (2002) A three-year record of simultaneously measured aerosol chemical and optical properties at Barrow, Alaska. J Geophys Res. doi:10. 1029/2001JD001248

Quinn PK, Shaw G, Andrews E, Dutton EG, Ruoho-Airola T, Gong SL (2007) Arctic haze: current trends and knowledge gaps. Tellus 59B:99-114

Saltzman ES (1995) Ocean/atmosphere cycling of dimethylsulfide. In: Delmas RJ (ed.) Ice core studies of global biogeochemical cycles. Berlin: Springer-Verlag, pp 65-90 (NATO ASI Series I: Global Environmental Change 30) 
Scheuer E, Talbot RW, Dibb JE, Seid GK, DeBell L, Lefer B (2003) Seasonal distributions of fine aerosol sulfate in the North American Arctic basin during TOPSE. J Geophys Res 108(D4):8370. doi:10.1029/2001JD001364

Teinilä K, Hillamo R, Kerminen V-M, Beine HJ (2003) Aerosol chemistry during the NICE dark and light campaigns. Atmos Environ 37:563-575

Teinilä K, Hillamo RE, Kerminen VM, Beine HJ (2004) Chemistry and modal parameters of major ionic aerosol components during the NICE campaigns at two altitudes. Atmos Environ 38:1481-1490

Tunved P, Ström J, Krejci R (2013) Arctic aerosol life cycle: linking aersol size distributions observed between 2000 and 2010 with air mass transport and precipitation at Zeppelin station, NyÅlesund, Svalbard. Atmos Chem Phys 13:3643-3660. http:// www.atmos-chem-phys.net/13/3643/2013/. doi:10.5194/acp-133643-2013

Turnipseed AA, Barone SB, Ravishankara AR (1996) Reaction of OH with dimethyl sulfide. 2. Products and mechanisms. J Phys Chem. 100:14703-14713

Udisti R, Becagli S, Benassai S, Castellano E, Fattori I, Innocenti M, Migliori A, Traversi R (2004) Atmosphere-snow interaction by a comparison between aerosol and uppermost snow layers composition at Dome C (East Antarctica). Ann Glaciol 39:53-61

Udisti R, Dayan U, Becagli S, Busetto M, Frosini D, Legrand M, Lucarelli F, Preunkert S, Severi M, Traversi R, Vitale V (2012) Sea-spray aerosol in central Antarctica. Present atmospheric behavior and implications for paleoclimatic reconstructions. Atmos Environ 52:109-120. doi:10.1016/j.atmosenv.2011.10. 018
Udisti R, Becagli S, Frosini D, Ghedini C, Rugi F, Severi M, Traversi R, Zanini R, Calzolai G, Chiari M, Lucarelli F, Nava S, Ardini F, Grotti M, Vione D, Malandrino M, Bolzacchini E, Ferrero L, Perrone MG, Sangiorgi G, Francesconi S, Giannarelli S, Cappelletti D, Moroni B, Ceccato D, Mittner P, Sartori P (2013) Activity and preliminary results from the 2011 and 2012 field seasons at $\mathrm{Ny}$ Ålesund. In: Research Activity in Ny Ålesund 2011-12. CNR Editions DTA/14-2013. ISSN 2239-5172, pp 53-68

VanCuren RA, Cahill T, Burkhart J, Barnes D, Zhao Y, Perry K, Cliff S, McConnel J (2012) Aerosols and their sources at Summit Greenland-first results of continuous size- and time-resolved sampling. Atmos Environ 52:82-97

Viola A, Vitale V, Petroni I, Tampieri F, Mazzola M, Lanconelli C, Busetto M, Lupi A, Di Liberto L, Conidi A, Ianniello A, Salvatori R, Esposito G, Spataro F, Udisti R, Becagli S, Frosini D, Ghedini C, Traversi R, Cappelletti D, Valt M, Turetta C (2013) Atmospheric studies at "Dirigibile Italia". In: Research Activity in Ny Ålesund 2011-12. CNR Editions DTA/14-2013. ISSN 2239-5172, pp 35-51

Wagenbach D, Preunkert S, Schäfer J, Jung W, Tomadin L (1996) Northward transport of Saharan dust recorded in a deep alpine ice core. In: Guerzoni S, Chester R (eds.) The impact of desert dust across the mediterranean. Environmental Science and Technology Library, vol. 11. Springer, The Netherlands, pp 291-300

Wolff EW, Fischer H, Fundel F, Ruth U, Twarloh B et al (2006) Southern Ocean sea-ice extent, productivity and iron flux over the past eight glacial cycles. Nature 440: 491-496. doi:10.1038/ nature 04614 